\title{
A Curriculum Development of Coffee Barista Education
}

\author{
Adi Prehanto ${ }^{1}$, Haryono ${ }^{2}$, Tri Joko Raharjo ${ }^{3}$ \\ Universitas Pendidikan Indonesia ${ }^{1}$, Universitas Negeri Semarang ${ }^{2,3}$ \\ \{adiprehanto2020@upi.edu로.,haryono.unnes@gmail.com², trijokoraharjo@mail.unnes.ac.id ${ }^{3}$ \}
}

\begin{abstract}
The aim of the study developed a coffee barista education curriculum. This study focused on four developed components, comprised objectives, learning experiences, organizing learning experience, and evaluation or achievement of the curriculum. Research methodology based on research and development methods. Data collection techniques applied structured interviews and direct observation. The subjects were participants of barista training that never been participated in any barista training before. The results of this study found that the Barista education curriculum was effectively Implemented. Through this research, would have been create a guideline or authentic script the Barista Education Curriculum. This research would also strengthen theory of curriculum development, where the legitimacy of curriculum development needed to be developed continuously, in order to get tentative goals.
\end{abstract}

Keywords: Barista Coffee, Coffee Industry, Curriculum, Curriculum Development

\section{Introduction}

Life continues to evolve, along with human needs so. For the current era, 21 st century identically refers to technological advances and internet of things. This era runs very quickly than everyone realizes (Talmi, et. al. 2018). This modern era was rapidly getting various changes, especially for information technology. Yet, this phenomenon and change affected on various human aspect lines, such as industry, economy, culture, politics, social, communication, transportation, and even education. This unconscious progression brought the different creative thoughts of the previous era (Kasali, 2017). One of the many creative industries that people interested was the coffee industry. Globally, Indonesia is one of the largest coffee producing countries in the world. In 2010, Indonesia ranked forth as coffee producer, under Brazil, Vietnam, and Columbia (Panggabean, 2012). In the year 2017-2018, Indonesia still became the big four as the largest coffee producer in the world. This potential resource became an evident for Indonesia to be developed for the prosperity of Indonesian society. This success, influenced the development of coffee shops industry in Indonesia especially. Many coffee outlets, both traditional and modern scattered in various cities in Indonesia in particular. Development of potential content when supported positively, would be a markeplacet or new space for some communities to develop a wealth or advanced of regions. 
Indonesia is officially as the large country producing coffee in the world, in addition to Brazil, Vietnam, and Venezuela (figure 1.1, (Resource: https://www.bbc.com/indonesia/majalah-43772934). This was a great potential strength for Indonesia in developing resources and economics, as well as industry. Coffee Industry is now popular among the all communities, both low and middle. Everyone could enjoy drinking coffee in any places. Many places or spaces sell coffee drinks as potential remarkable in business. It make people eagerly want to open coffee industry.

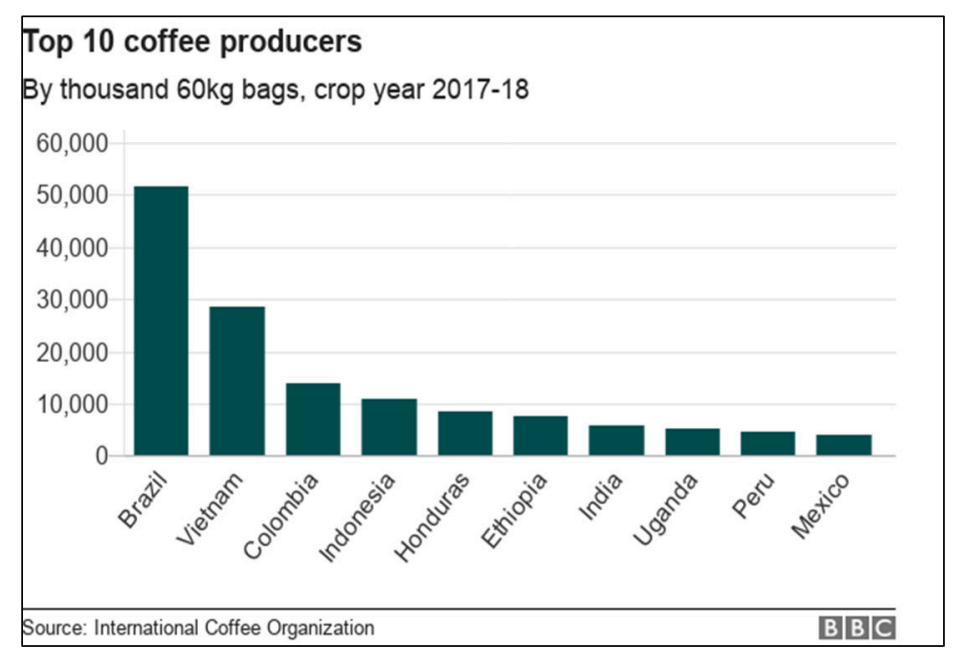

Fig. 1. Rank of World Coffee Production

In coffee industry, coffee shops in particular, there is a profession known as a coffee barista. This profession is a man or woman who gets responsible for the making or producing beverages based of coffee. One of the responsibilities of the barista, could serve coffee drinks according to the interests or tastes of the buyer. It was not easy at all, because the barista needed to have the ability to understand coffee characteristics to serve drinks deeply. In fact, they should have an understanding or a tool in the coffee-making, so that the desired sense of character could exist. The presence of a barista did not only bring benefits or comfortable to customers, but for the owners of coffee shops also got benefit. This existence increased the income and the number of customers (economical aspect) coming and useful for managers of coffee outlets (Amador, 2012). However, being the culture of drinking coffee in any places, barista profession did not talk just a coffee-making drink. However, all baristas should have other competencies or skills, to support as a real professional barista. This problem related to the barista's ability within communication and giving service to customers. Many baristas had not been had such those abilities yet. It was due to the development of career or competence only in the work environment, without the other skills being supported. Definitely, the certain problem was on the management of education or training of the barista profession had not been yet prepared very well by government or education institution. The competence of barista was only gained by the time working in a café or restaurant only. Strengthening the competence of a professional barista was not maximally increased, included good competency, knowledge, skill even. The standard of training institutions and education barista did not exist in teaching or training indeed. 
To be a competent person in this field, should be passed through proper and good training or education. Education sector played an important role in developing the potential of quality resources (Tobing, 2018). This training, non-formal education, were able to help the development and keep of competencies needed than doing in formal education. The role of educational institutions was as a core and important within building the capacity of a nation and society (Haryono, et. AL, 2018). The educational institution served as a facility, should equip learners with relevant skills and competences, based on the interest. It was contained the attitude, cognitive, or psychomotor competence. These aspects were indispensable in forming intact character with attention to the needs and circumstances of the environment. Education positioned as a provision for someone to do the outside world. Thus, the supply of professional barista competence should be done through training or structured education, in the form of guidelines or curriculum, especially the barista education curriculum. However, the gaps were still few training institutions that know the function of curriculum documents and develop the curriculum. This was about to the competence possessed and the passion for improving the quality of education.

These problems were relevant in coffee industry and many coffee baristas. There were much complained for barista and resulting in a decline in quality and insertion. Through this problem, raised the novelty about the development of the Barista education curriculum, which created competent and professional barista. The purpose of this study developed a curriculum of professional barista education. Through the development of this product, it would be expected to produce professionals who have professional barista competence.

\section{Reseaerch Methodology}

The study implemented research and development methods based on Sugiyono level 3. On the design of this study, which became characteristic developed of existing products, forms and or functions, to be reperfected (Sugiyono, 2015:44-46). On the research and development of the curriculum in particular, rearranging the curriculum based on real things or facts in the field. The products produced in this research were the development of the structured barista professional curriculum. The steps design of the study were divided into three (3) Stages of research, consisting of preliminary studies, product development, and trial. At the trial stage of this study, was a limited trial (Sukmadinata N. S., 2016).

Preliminary data sources got through interviews with coffee industry practitioners, coffee baristas, and an assessor of coffee Certification board, the related sources. Documentation done at several barista training institutes and employment departments. Product development compeleted by 2 stages ofvalidity test, internal and external. External tests purposed to determine the effectiveness of curriculum products.

\section{Result and Discussion}

\subsection{Preliminery Study}

Ramadan (2017) and Hutasoit, et.al (2018), presented in their research, the problem that a barista owned was about the ability to communicate and provide service in accordance with professional standards. The role of barista became important in a coffee booth or café, to bring more profit for the owner of the store. Many customers came to a café not only to enjoy coffee 
drinks that formulated by a barista only. However, they came to feel an impression and a service that suits what they paid for. This was obvious that the role of a barista was not only good at making coffee-made drinks, but able communicate and provided a good and professional service to the buyer. Anisailah (2017) stated that the presence of an in-store or coffee café was important in increasing income. However, it required a barista that actually had the relevant capabilities or competence. Barista education or training required to equip the candidates or young baristas who got desire to develop self-professionalism.

In addition, the results in some of the barista training in Semarang City showed that it did not have a document or a suitable learning device standard. This related with the establishment of barista classes in Semarang city was still as a new . Another thing was these two institutions did not yet have experts involved in drafting the curriculum documents and training of barista education. The following field mapping displayed, related to the availability of barista education learning devices at KnK Coffee class and Boskaf Studio Coffee.

Table 1. Mapping of KNK Coffee Class

\begin{tabular}{lll}
\hline & Available & Not available \\
\hline Curriculum Document & & $\sqrt{ }$ \\
Syllabus and Lesson Plan & & $\sqrt{ }$ \\
Teaching & $\sqrt{ }$ & \\
Content & $\sqrt{ }$ & \\
Aids and media & $\sqrt{ }$ & $\sqrt{ }$ \\
Handbooks & & $\sqrt{ }$ \\
\hline
\end{tabular}

Table 2. Mapping of Boskaf Coffee Studio

\begin{tabular}{lll}
\hline & Available & Not available \\
\hline Curriculum Document & & $\sqrt{ }$ \\
Syllabus and Lesson Plan & & $\sqrt{ }$ \\
Teaching & $\sqrt{ }$ & \\
Content & $\sqrt{ }$ & \\
Aids and media & $\sqrt{ }$ & \\
Handbooks & $\sqrt{ }$ & \\
\hline
\end{tabular}

The next preliminary study obtained was the standard competencies as a professional barista, based on Indonesia Competence Standard (SKKNI). Many of the baristas learnt making coffee and hospitality only from working in a café. This made a problem that competence to become a professional barista had not been obtained optimally. Therefore, it would not be common for the barista to get complaints from customers, especially in serving and communicating. The table below was the standard work competencies of a professional barista.

Table 3. Indonesia Standard of Profesional Skills (SKKNI)

\begin{tabular}{ll}
\hline \multicolumn{1}{c}{ Code } & \multicolumn{1}{c}{ Competences or Skills } \\
\hline I.563030.001.01 & Managing raw Materials \\
I.563030.002.01 & Managing Equipment and Supplies \\
I.563030.003.01 & Managing Work Area \\
I.563030.004.01 & Handling Customers \\
I.563030.005.01 & Operating Equipment \\
I.563030.006.01 & Developing Coffee Beverages Products \\
PAR.UJ01.003.01 & Managing the health, safety and safety procedures in the workplace \\
PAR.UJ01.004.01 & Managing conflict situations \\
PAR.UJ03.044.01 & Communication skills, both written and spoken \\
\hline
\end{tabular}




\subsection{Developing Curriculum of Coffee Barista}

The barista curriculum development consisted of developing objective or goal, content, process, and evaluation (the effectiveness of curriculum). The purpose of the barista education curriculum developed as the vision of a barista class or institution. Then, it became an institution that built or created professional barista with an insightful of Indonesia coffee. It fully reflected on the standards of Indonesian barista profession and the problems that occured.

Based on previous preliminary studies, through this study developed a professional barista education curriculum in accordance with Indonesian standards and additions based on popular or update barista needs. Aspects of knowledge, skills, and attitude became the main priority that should be possessed by professional barista. The subjects material divided into nine training points or materials, in accordance with Indonesia's National working Competency Standards (SKKNI) and the minimal skill of coffee-making.

Table 4. Curriculum Structure

\begin{tabular}{ll}
\hline \multicolumn{1}{c}{ Contents } & \multicolumn{1}{c}{ Subject Materials } \\
\hline Type of coffee (World and Indonesia) & Orientation of Coffee \\
Characteristics of Coffee & \\
Anatomy of Coffee & \\
History of Coffee & Barista as a Professional \\
History of An barista & \\
Understanding of An Barista & \\
Jobs of An Barista & Quality Assurance of Coffee \\
Grading of Coffee & \\
Sortiring & \\
Quality Control & Methodology of Brewing Coffee \\
Anatomy of Tongue & \\
Assessment Methodology of Coffee Grading & \\
Manual brew Technique & Kinds of Coffee drinks \\
Machine Technique & \\
Coffee by manual brew & \\
Coffee by machine & Coffee processing \\
Traditional coffee & Occupation Health and Safety \\
Scheme of Coffee processing & \\
Occupation Health and Safety & Management of work Area and materials \\
Treat the tools & \\
Workflow and area layout & \\
Managing materials & \\
Pop culture of drinking coffee & \\
Developing Coffee & \\
Developing tools & Developing Barista and coffee \\
Barista Competition & \\
Latte art (optional) & \\
\hline
\end{tabular}

Furthermore, the development of a barista-class process or strategy implemented by andragogy method (maturity thoughts), emphasizing the strengthening skills as a professional barista. This curriculum organized hierarchical, where prospective barista needed to finish each course according to the burden or level. Level I included coffee orientation and barista profession. Level II included the Tasting and Quality Assurance of Coffee, tools operation and methods of brewing coffee, Kinds of Coffee drinks, and coffee processing. Level III covered 
Occupation Health and Safety, Management of work Area and materials, and Developing Barista and coffee.

The development of the barista curriculum evaluation done through some assessment of learning outcomes, including assessment of knowledge, skills, and attitudes, which prepared in the form of tests and non tests. More, to determine the implementation of this curriculum, evaluation strengthened through the observation of the instructor and the experience of the barista class participants. At the end of the training, participants would fill a quentioner of impression, after they completed training and education of barista class.

\subsection{Validity of Barista Education Curriculum}

The Barista curriculum feasibility test conducted through internal tests by experts, both from curriculum experts and barista material experts. The feasibility of document and curriculum structure was in accordance with the rules of drafting and curriculum content. Content qualification according to experts accorded to the needs of barista and coffee material for beginner level. The goal wanted to achieve was relevant to the materials presented in the barista curriculum. The use of Indonesia Language in the handbook made easy to understand by instructors and participants. However, there were terms that written in English, so the participants needed to explore the information from other sources by them self.

Table 5. Validity of Curricullum

\begin{tabular}{|c|c|c|}
\hline & Indikacor & Criteria \\
\hline \multirow[t]{23}{*}{ A } & General background & \\
\hline & Rationale & Good \\
\hline & 1. Logic & \\
\hline & 2. Resources & Good \\
\hline & Law Foundation & \\
\hline & 3. Indonesia Constitution state of 1945, number $31: 1$ & Good \\
\hline & 4. Indonesia Regulation number 20 of 2003: national education system & Good \\
\hline & Vision, Mission, and Goal & \\
\hline & Vision: & Good \\
\hline & 5. Compact (practical) and easy to understand & \\
\hline & 6. Referring to the achievement demands of graduates & Good \\
\hline & $\begin{array}{l}\text { 7. Oriented towards the self potential, development, needs and interests of the } \\
\text { trainees }\end{array}$ & Good \\
\hline & 8. Inspiring and challenging in improving performance sustainably & Good \\
\hline & $\begin{array}{l}\text { 9. Directing strategic measures to describe the mission of education and training } \\
\text { organizers }\end{array}$ & Good \\
\hline & Mission: & Good \\
\hline & 10. Describes the vision of a measurable and achievable statement & \\
\hline & Goal: & Good \\
\hline & $\begin{array}{l}\text { 11. Defines mission achievement in the form of measurable and achievable } \\
\text { statements }\end{array}$ & \\
\hline & Structure of Curriculum & \\
\hline & $\begin{array}{l}\text { 12. Lists of curriculum structure that contains the training eye according to the } \\
\text { needs and research materials relevant to the profession of barista Nusantara. }\end{array}$ & Good \\
\hline & $\begin{array}{l}\text { 13. Training activities include processes or methods of training and education that } \\
\text { correspond to the characteristics of the trainees. }\end{array}$ & Good \\
\hline & $\begin{array}{l}\text { 14. Training time allocation setting is tailored to the needs of the trainer with a } \\
\text { face-to-face hourly breakdown and number of hours per week }\end{array}$ & Good \\
\hline & Final Assessment & \\
\hline
\end{tabular}




\begin{tabular}{|c|c|c|c|}
\hline \multicolumn{3}{|c|}{ Indikacor } & Crite \\
\hline \multicolumn{4}{|c|}{ 15. Consists of the training's guidance and assessment procedures. } \\
\hline \multicolumn{4}{|c|}{ 16. Includes training final assessment criteria } \\
\hline \multicolumn{4}{|c|}{ Attachment Syllabus and lesson plan } \\
\hline \multicolumn{4}{|c|}{$\begin{array}{l}\text { 17. The full syllabus contains the standard of graduates ' competence, basic skills, } \\
\text { indicators, training materials, trainings, assessments, time allocation, and } \\
\text { learning resources. }\end{array}$} \\
\hline \multicolumn{4}{|c|}{$\begin{array}{l}\text { 18. Lesson plan contains basic components: the name of the government, time } \\
\text { allocation, materials, achievement indicators, methods, teachers, final ability, } \\
\text { time allocation, indicators, evaluation, and value weights. }\end{array}$} \\
\hline \multicolumn{4}{|c|}{ Table 6. Validity of Content } \\
\hline Assessment Indicator & Items & \multicolumn{2}{|c|}{ Criteria } \\
\hline \multirow[t]{3}{*}{ 1. Materials appropriate with goals } & 1. Completeness of material. & \multicolumn{2}{|c|}{ Good } \\
\hline & 2. Material expanse. & \multicolumn{2}{|c|}{ Very good } \\
\hline & 3. Depth of material. & \multicolumn{2}{|c|}{ Good } \\
\hline \multirow[t]{7}{*}{ 2. Accuracy of the materials } & $\begin{array}{l}\text { 4. Accuracy of concepts and } \\
\text { definitions. }\end{array}$ & \multicolumn{2}{|c|}{ Good } \\
\hline & 5. Accuracy of data and facts. & \multicolumn{2}{|c|}{ Good } \\
\hline & 6. Example and case accuracy. & \multicolumn{2}{|c|}{ Good } \\
\hline & $\begin{array}{l}\text { 7. Accuracy of images, diagrams } \\
\text { and illustrations. }\end{array}$ & \multicolumn{2}{|c|}{ Good } \\
\hline & 8. Accuracy of terms. & \multicolumn{2}{|c|}{ Good } \\
\hline & $\begin{array}{l}\text { 9. Accuracy of notation, symbols } \\
\text { and icons. }\end{array}$ & \multicolumn{2}{|c|}{ Good } \\
\hline & 10. Accuracy of the reference. & \multirow{2}{*}{\multicolumn{2}{|c|}{$\begin{array}{c}\text { Good } \\
\text { Very good }\end{array}$}} \\
\hline \multirow[t]{5}{*}{ 3. The establishment of material } & $\begin{array}{l}\text { 11. Material suitability with the } \\
\text { development of coffee and barista }\end{array}$ & & \\
\hline & $\begin{array}{l}\text { 12. Examples and cases based on } \\
\text { everyday life. }\end{array}$ & \multicolumn{2}{|c|}{ Very good } \\
\hline & $\begin{array}{l}\text { 13. Drawings, diagrams and } \\
\text { illustrations in everyday life. }\end{array}$ & \multicolumn{2}{|c|}{ Good } \\
\hline & $\begin{array}{l}\text { 14. Using examples of cases } \\
\text { contained in daily life. }\end{array}$ & \multicolumn{2}{|c|}{ Good } \\
\hline & 15. Establishment of reference & \multicolumn{2}{|c|}{ Good } \\
\hline \multirow[t]{2}{*}{ 4. Encouraging curiosity } & 16. Encouraging curiosity & \multirow{2}{*}{\multicolumn{2}{|c|}{$\begin{array}{l}\text { Good } \\
\text { Good }\end{array}$}} \\
\hline & 17. Creating the ability of Asking & & \\
\hline
\end{tabular}

\subsection{The Effectivness of Curriculum}

The ability of the initial participant was zero, not to get barista training before. It had been known by fisrt intervew and written test. Then, each participants shuld finish the written tests and practical tests. The effectiveness of Barista education curriculum was well-tested and able to equip the prospective professional barista in the field of work. This proved in the pre-test and postest results that have significantly improved. More, it was also supported by an instructor observation that sees the participants ' ability increased. To be more effective, the training and education class needed a habituation in making drinks and communicating gradually. In addition, participants were also aware of their respective abilities before they received training and after training. The effectiveness of this curriculum would be shown optimally also done with continous habituation and motivation of high learning. 
Table 7. Pretes and Postest

\begin{tabular}{cccccc}
\hline \multirow{2}{*}{ Name } & \multirow{2}{*}{ Cognitive } & \multirow{2}{*}{ Attitude } & \multicolumn{3}{c}{ Skills } \\
\cline { 4 - 6 } & & & Manual Brew & Machine & Coffee Grading \\
\hline WIka & 47 & 95.2381 & 77.77778 & 91.66667 & 66.66667 \\
Putra & 48 & 85.71429 & 66.66667 & 58.33333 & 66.66667 \\
Zidane & 52 & 95.2381 & 77.77778 & 83.33333 & 77.77778 \\
Imron & 21 & 76.19048 & 66.66667 & 83.33333 & 44.44444 \\
\hline
\end{tabular}

Curriculum development got to reach the deepest realm of a curriculum as a whole (Sanjaya. 2012:77). Rusman and Rohman (2017), Kurniawan and Utanto (2018) stated the same analysis of relevant needs and problems made a benchmark in the development of curriculum components. The development of the barista curriculum included the development of objectives, content or experience, organizing learning, and evaluation. The content or material of this curriculum had been adapted to SKKNI, the standard barista profession and the need became a profesional coffee barista. However, this comprehensive curriculum design needed to be supported from the interest of participants or learner. The instructor should provide complete assessment and detail to the development of the trainees, to make sure the lesson gained effectively. Thus, the instructor required to be more active and skillful (multitasking) for supporting the instruction or learning.

This condition was strengthened also by the research of Alsubaie (2016), stated the development of the curriculum was a continuous process. It refers to some needs of learners, to improve the competence of the participants of learning and not only be a written document (regulation), but must be embedded and valuable. The development or alteration of the curriculum meant a progress in the value or quality of education (Nasution, 2014). Curriculum was a reference or guideline in the implementation to achieve a desired purpose (Sanjaya, 2012). The curriculum developed as a structured guideline that defines objectives, content, activities as a learning experience, and assessment (Sukmadinata N. S., 2012).

\section{Conclusion}

Curriculum of barista existed as a comprehensive guideline or reference to help instructor or management of the barista training to achieve the objective of education. The barista education curriculum should be designed structured, according to the competence or ability required. This concept designed in the form of a competency based barista education curriculum. The development of the Barista Education curriculum included four determined aspects namely, developing objectives, provision of competence, organizing the materials (procces), and the effectiveness of the curriculum. Curriculum development was transforming the curriculum from ideas into written guidelines. Development of the Barista education curriculum intended as an effort to improve the competence of people in the field of barista and coffee. To be more effective, the education process should be supported by the high interest of participant learning and the ability of instructor developed the teaching process. The development of the barista curriculum should be developed sustainably, given the needs and developments of the era. Research in the field of development of barista education curriculum is still slightly found. However, this study became an initiated work for academics or utilities who had an interest in research and development of educational curriculum, both formal and informal.

Education purposed to provide or prepare people with the ability within overcoming existing problems. Education or training was a recommend way for improving and equipping 
individuals with these competencies needed. Barista education was part of a non-formal education or outside school education (PLS), as a form of creative existence of educational development. So far, in an effort to fulfill and improve the competence of becoming a professional barista, they completed through the work in restaurants or coffee outlets. It made they did not get fully competences or skill in barista professional.

\section{References}

[1] Alsubaie, M. A. (2016). Curriculum Development: Teacher Involvement in Curriculum Development. Journal Of Education and Practice. ISSN 2222-1735 (Paper) ISSN 2222-288X, Vol.7, No.9. 106-107.

[2] Amador, A. A. (2012). Pengaruh Kualitas Produk dan Kualitas Pelayanan Terhadap Sikap Konsumen Dan Implikasinya Terhadap MInat Beli Ulang. Semarang: FEB Universitas Diponegoro.

[3] Anisailah, R. (2017). Analisis Kualitas Produk Dan Kualitas Pelayanan Barista Di Krema Koffie Pekanbaru. JOM FISIP, Vol. 4 No. 1 . 1-17.

[4] Haryono, Prihatin, T., \& Widhanarto, G. P. (2018). Effectiveness study on applied quality assurance of ducational technology in learning quality improvement in universities. MATEC Web of Conferences 205, 00008 . https://doi.org/10.1051/matecconf/201820500008, 1-3.

[5] Hutasoit, R. A., Solikhun, \& Wanto, A. (2018). Analisa Pemilihan Barista Dengan Menggunakan Metode Topsis (Studi Kasus: Mo Coffee). KOMIK (Konferensi Nasional Teknologi Informasi dan Komputer). ISSN 2597-4645 (media online), Volume 2, Nomor 1, 256-162.

[6] Kasali, R. (2017). Disruption. Jakarta: PT Gramedia Pustakan Utama.

[7] Kurniawan, D. M., \& Yuli , U. (2018). Kurikulum Bela Negara Sebuah Kebutuhan Kurikulum Saat Ini Dan Masa Depan. DEFENDONESIA. ISSN 2354-6964, Volume 3 Nomor 2. 1-12.

[8] Nasution, S. (2014). Asas-Asas Kurikulum. Jakarta: PT. BUMI AKSARA.

[9] Ramadhan, F. (2017). Makna Kerja BAgi Barista. Jurnal Skripsi Universitas Islam Indonesia, 17.

[10] Rusman, \& Rohman, A. (2017). Development of Training Curriculum in Improving Community-Based Geological Hazard MitigationCompetency. MIMBAR. ISSN 02158175 | EISSN 2303-2499, Vol. 33, No. 2. 416-425.

[11] Sanjaya, W. (2012). Kurikulum Dan Pembelajaran. Jakarta: KENCANA PRENADA Group.

[12] Sugiyono. (2015). Metode Penelitian Dan Pengembangan. Bandung: CV ALFABETA.

[13] Sukmadinata, N. S. (2016). Metode Penelitian Pendidikan. Bandung: PT. Remaja Rosdakarya Offset

[14] Talmi, I., Hazzan, O., \& Katz, R. (2018). Intrinsic Motivation and 21st-Century Skills in an Undergraduate Engineering Project: The Formula Student Project. Higher Education Studies. ISSN 1925-4741 E-ISSN 1925-475X, Vol. 8, No. 4. 46-58.

[15] Tobing, J. (2018). Pendidikan Untuk Mencerdaskan Kehidupan Bangsa. Ketatanegaraan. ISSN: 2548-4389, Vol.007. 85-100. 